\title{
KEANEKARAGAMAN SATWA LIAR PADA TEGAKAN JATI UNGGUL NUSANTARA (JUN) UMUR 5 TAHUN DI KEBUN PERCOBAAN UNIVERSITAS NUSA BANGSA, BOGOR
}

\author{
Taofik Herdian Nugraha, Tun Susdiyanti* dan Luluk Setyaningsih \\ Fakultas Kehutanan UNB Bogor \\ Jl. K. H. Soleh Iskandar Km. 4, Cimanggu, Tanah Sareal - Bogor 16166 \\ *Email : sylvia_UNB@ymail.com Telp. 0252-8340217, 7535605
}

\section{ABSTRACT
Diversity of Wildlife in Stands of Nusantara Superior Teak (JUN) Age 5 Years Old in Nusa Bangsa University Experimental Garden, Bogor

\begin{abstract}
Habitat is a place or environment where wildlife get a source of food, water and shelter in order to meet the needs of their lives including support for the breed. Its presence in of activity of human life can be an indicator of naturalness of an area. This study aimed to identify the species of wildlife and to determined population density, abundance and diversity of wildlife found at the Experimental garden of University of Nusa Bangsa. This study had been done in 2009. The research method was a combination methods abundance point method and strip transect. This method could be done for mamalia, aves and reptiles observation and was intended to obtain data of wildlife with having higher contact chance. Pathways methods for mammals observations and point method for observation of reptiles and aves. Results of previous studies identified had a total of 19 wildlife species from three classes (reptiles, aves and mammals). Wildlife populations identified in the Experiment were 891 individuals and the abundence of 89.1 individu/Ha. Wildlife Species Diversity at the Experiment classified as moderate with a score index value of 2.361. The wildlife was most commonly found were Cattle Swallow, Home Kapinis and Rice Cici. While in the 2011 study identified as many as 16 wild animals of the three classes of animals (reptiles, aves and mammals), among others Gardens Lizard, Koros Snake, Ropes Picis Snake, Mandy Gray Birds, Quail, Cattle Swallow, Kapinis, turtledoves, Perenjak, Kutilang, Bananas Cinenen, Rice Cici, Sparrow, Sparrow/Scaly, grate and Bats. Wildlife populations identified in the Experiment were 137 idividu and the abundance of 13.7 individu/Ha2. Wildlife Species Diversity at the Experiment classified as moderate with a index score of 2.35. The wildlife was most commonly found Cattle Swallow, Kutilang, garden lizards and turtledoves.
\end{abstract}

Keywords : Biodiversity, wildlife, habitat, experimental gardens UNB

\begin{abstract}
ABSTRAK
Habitat adalah suatu tempat atau lingkungan dimana satwaliar mendapatkan sumber makanan, air dan perlindungan (shelter) guna memenuhi kebutuhan untuk menunjang kehidupan mereka termasuk diantaranya untuk beranak pinak atau berkembang biak. Keberadaannya ditengah - tengah aktifitas dan kehidupan manusia dapat menjadi indicator akan kealamian suatu wilayah. Penelitian ini bertujuan untuk mengidentifikasi jenis satwa liar dan untuk mengetahui kepadatan populasi, kelimpahan serta keanekaragaman jenis satwaliar yang terdapat di Kebun Percobaan UNB. Penelitian ini merupakan penelitian yang telah dilakukan pada tahun 2009. Metode penelitian dengan metode gabungan antara metode kelimpahan titik (point of abundance) dan transek jalur. Dengan metode ini dapat dilakukan untuk pengamatan mamalia.aves dan reptile sekaligus serta dimaksudkan untuk memperoleh data tentang satwaliar dengan peluang kontak yang lebih tinggi. Metode jalur untuk pengamatan mamalia sedangkan metode titik untuk pengamatan reptil dan aves. Hasil penelitian sebelumnya teridentifikasi sebanyak 19 satwa liar dari tiga kelas satwa (reptile, aves dan mamalia). Populasi satwa liar yang teridentifikasi di Kebun Percobaan UNB sebesar 891 individu dan jumlah kelimpahannya sebesar 89,1 individu $/ \mathrm{Ha}^{2}$. Keanekaragaman Jenis Satwa Liar di Kebun Percobaan UNB tergolong sedang dengan nilai indeks sebesar 2,361. Satwa liar yang paling banyak ditemukan adalah Walet Sapi, Kapinis Rumah dan Cici Padi. Sedangkan pada penelitian 2011 teridentifikasi sebanyak 16 satwa liar dari tiga kelas satwa (reptile, aves dan mamalia) antara lain Kadal Kebun, Ular Koros, Ular Tali Picis, Burung Wiwik Kelabu, Burung Puyuh, Walet Sapi, Kapinis, Tekukur,Perenjak, Kutilang, Cinenen Pisang, Cici Padi, Burung Gereja, Burung Pipit/Bondol, Garangan, dan Kalong. Populasi satwa liar yang teridentifikasi di Kebun Percobaan UNB sebesar 137 individu dan jumlah kelimpahannya sebesar 13,7 individu/Ha2. Keanekaragaman Jenis Satwa Liar di Kebun Percobaan UNB tergolong sedang dengan nilai indeks sebesar 2,35. Satwa liar yang paling banyak ditemukan adalah Walet Sapi, Kutilang, kadal kebun dan Tekukur.
\end{abstract}

Kata Kunci : Keanekaragaman, satwaliar, habitat, kebun percobaan UNB 


\section{PENDAHULUAN}

Habitat adalah suatu tempat atau lingkungan dimana satwaliar mendapatkan sumber makanan, air dan perlindungan (shelter) guna memenuhi kebutuhan untuk menunjang kehidupan mereka termasuk diantaranya untuk beranak pinak atau berkembang biak. Kebun Percobaan Universitas Nusa Bangsa (UNB), di daerah Cogreg adalah salah satu tempat yang memungkinkan untuk menjadi habitat bagi satwa liar, dikarenakan tempat atau arealnya yang luas, banyaknya sumber air dan makanan, serta masih banyaknya daerah yang cukup alami dan relatif sedikit mendapatkan gangguan berarti dari sejumlah aktifitas manusia yang hidup di sekitar Kebun Percobaan UNB.

Pada areal ini terdapat tegakan Jati Unggul Nusantara (JUN) varietas jati baru yang bersifat fast growing yang didapat melalui proses kultur jaringan. JUN sebagai tegakan mempunyai potensi sebagai elemen penting di dalam habitat satwaliar. Demikian pula dengan keberadaan tanaman lain yang berupa tanaman tumpang sari seperti terung, jagung, kacang panjang, singkong, cabai dan papaya

Satwa liar sendiri merupakan
indikator yang menarik untuk diteliti.Keberadaannya ditengah - tengah aktifitas dan kehidupan manusia dapat menjadi warna dan arti tersendiri.Jika satwaliar dapat di temukan pada suatu wilayah yang dihuni dan dipenuhi oleh aktifitas manusia, maka dapat dipastikan bahwa lingkungan di sekitar lokasi aktifitas manusia tersebut masih dapat dikatakan alami.Namun ada juga beberapa satwaliar yang mampu beradaptasi dengan sejumlah aktifitas manusia di lingkungan sektiar habitat mereka. Jika dilihat dari jumlah dan populasinya, satwaliar dapat dijadikan indikator bagi lingkungan yang sudah ataupun belum tercemar (Kurnia, 2003).

Sampai saat ini sebaran keragaman satwa liar yang terdapat pada tegakan JUN di Kebun Percobaan UNB, Cogreg belum diketahui.sehingga penelitian ini perlu untuk dilakukan.Penelitian ini merupakan penelitian lanjutan yang telah dilakukan pada tahun 2009 pada saat umur jati sekitar 2 tahun. Dan saat ini umur tegakan jati unggul nusantara telah memasuki tahun ke 4 sehingga keanekaragaman jenis satwa liar belum diketahui.

\section{Rumusan Masalah}

Sebaran keanekaragaman satwa liar di tegakan JUN yang merupakan jati varietas baru dengan umur tegakan memasuki tahun ke 4 belum pernah diteliti sehingga data mengenai kelimpahan satwa liar belum.

\section{Tujuan Penelitian}

Penelitian ini ditujukan untuk :

1. Identifikasi jenis satwa liar Kebun Percobaan UNB

2. Mengetahui kepadatan populasi, kelimpahan dan keanekaragaman jenis satwaliar yang terdapat di Kebun Percobaan UNB, Cogreg

\section{Manfaat Penelitian}

1. Mengetahui potensi dan manfaat ekologis yang lebih dalam dari JUN dari sekedar tanaman yang komersial, sehingga meningkatkan nilai dari JUN

2. Memberikan gambaran terhadap kondisi lingkungan di Kebun Percobaan UNB Cogreg, dengan keberadaan dan keanekaragaman satwa liar sebagai indikatornya

\section{BAHAN DAN METODE}

\section{Lokasi dan Waktu}

Lokasi penelitian dilaksanakan di Kebun Percobaan Universitas Nusa Bangsa, Desa Cogreg, Kecamatan Parung, Kabupaten Bogor; Desember 2011.

\section{Alat dan Bahan}

Alat dan bahan yang diperlukan diantaranya: Tally Sheet dan alat tulis, Penanda waktu, Buku panduan lapang 
(Field Guide Book), Kamera Digital Canon EOS 550d, Binocullar danKompas.

\section{Batasan Penelitian}

1. Lokasi penelitian dikonsentrasikan pada area yang terdapat tegakan JUN di Kebun Percobaan UNB, Cogreg.

2. Satwa liar yang diidentifikasi hanya dari jenis aves, reptile dan mamalia

\section{Metode Pengumpulan Data}

Data yang di kumpulkan adalah :

1. Data Primer meliputi habitat (sumber air, jenis tanah, cuaca/iklim dan tanaman), dan satwa liar (jenis satwa liar, jumlah individu, pendugaan umur individu, waktu kontak dan ukuran)

2. Sedangkan data sekunder adalah datadata penunjang yang meliputi peta area kebun, peta monografi desa.

Pengambilan data satwa liar dilakukan dengan pengamatan langsung yang dilakukan melalui pendengaran, penglihatan, dalam jarak jauh dan dekat. Data satwa liar yang diambil mencakup jenis satwa, jumlah individu, pendugaan umur individu, waktu kontak dan ukuran.

\section{Prosedur pengamatan}

1. Penentuan unit contoh lokasi pengamatan

* Data mengenai sampel satwa liar diambil dengan metode gabungan antara metode kelimpahan titik (point of abundance) dan transek jalur. Dengan metode ini dapat dilakukan untuk pengamatan mamalia. aves, dan reptile sekaligus serta dimaksudkan untuk memperoleh data tentang satwaliar dengan peluang kontak yang lebih tinggi. Metode jalur untuk pengamatan mamalia sedangkan metode titik untuk pengamatan reptil dan aves

* Melakukan orientasi lapangan sebelum kegiatan inventarisasi satwa liar digunakan untuk menentukan letak awal pengamatan bentuk unit contoh : Seluruh area yang terdapat tegakan JUN menjadi objek untuk diamati, dengan luas area penelitian $10 \mathrm{Ha}$ dan unit contoh seluas $1 \mathrm{Ha}$, sebanyak 10 unit

* Menentukan dan menandai titik titik yang akan diamati. Titik awal untuk pengamatan kelimpahan titik dimulai pada jarak $\pm 100 \mathrm{~m}$ dari titik awal jalur pengamatan

* Pengamatan dilakukan dengan cara berjalan sepanjang jalur pengamatan, kemudian pada titik titik yang telah ditentukan pengamat berhenti untuk melakukan pengamatan selama 20-30 menit

2. Pengamatan karakteristik dan jumlah satwa liar

Pencatatan data sepanjang jalur mengikuti kaidah pada metode transek jalur, sedangkan pada titik pengamatan, pengamatan dilakukan setelah pengamat berhenti atau istirahat untuk memulihkan kondisi lingkungan selama 5 menit pertama

* Mengamati karakteristik dari setiap jenis satwa liar yang ada di dalam unit contoh dan mencatat data satwa liar baik yang berkontak langsung maupun tidak langsung (tidak harus berkontak langsung dengan satwa) dan mencakup jenis satwa, jumlah individu, pendugaan umur individu, waktu kontak dan ukuran. Adapun data yang dapat dicatat dari kontak tidak langsung dengan satwa antara lain : sarang, suara(call sign), jejak kaki(foot print) dan feses (Gambar 2.).

* Pencatatan jumlah individu dari hasil pengenalan suara dihitung hanya satu individu untuk setiap kelompok atau posisi kontak suara. Hal ini dilakukan untuk mengurangi terjadinya over- 
estimate walaupun berpotensi menjadi under-estimate. Namun jika telah diketahui jumlah rata rata individu anggota kelompok satwa, maka jumlah individu yang dicatat dapat menggunakan data data tersebut.

3. Waktu pengamatan satwa liar

Adapun penentuan waktu pengamatan satwa liar beradasarkan Moen (1973), H. S Alikodra (1990), Dorkas Soli (1999) dan Insan Kurnia (2003) dibagi menjadi :

a. Pengamatan aves

Jenis burung atau aves diamati pada pagi hari (pukul 05:00-10:00 WIB) dan sore hari (pukul 16:00-19:00 WIB)

b. Pengamatan reptile

Jenis reptil atau reptile diamati pada pagi hari (pukul $08: 00-10: 00$ WIB) dan malam hari (pukul 19:00 $22: 00 \mathrm{WIB}$ )

c. Pengamatan mamalia

Jenis mamalia diamati pada pagi hari (pukul 08:00 - 12:00 WIB) dan malam hari (pukul 19:00-22:00 WIB)

\section{Analisis Data}

Data dianalisa berdasarkan pengamatan dimana untuk satwa yang ditemukan banyak yang di identifikasi berdasarkan jenis, ukuran, bentuk dan warna. Demikian juga dengan tumbuhannnya. Beberapa satwa sudah di identifikasi dengan Buku Penuntun Lapang (John Mackinnon, 1993), setelah proses pengamatan di lapangan dilakukan. Proses identifikasi juga dibantu oleh penduduk sekitar kebun percobaan yang paham dengan jenis - jenis satwa liar.

Pendugaan kepadatan populasi berdasarkan metode gabungan dapat dilakukan dengan menggunakan persamaan King 1971 :

$$
\begin{aligned}
& \widehat{D} \mathrm{j}=\frac{\sum_{i=1}^{n} \mathrm{Xi}}{2 . L . w} \text { atau } \\
& \frac{\sum_{i=1}^{n} \mathrm{Xi}}{a} \ldots \ldots \ldots \ldots \ldots . .(\text { rumus } 1)
\end{aligned}
$$

\section{Keterangan :}

$$
\begin{aligned}
& \widehat{D} \mathrm{j}=\begin{array}{l}
\text { kepadatan populasi pada jalur } \\
\text { pengamatan ke } \mathrm{j}
\end{array} \\
& \mathrm{X}_{\mathrm{i}}=\begin{array}{l}
\text { jumlah individu yang dijumpai } \\
\text { pada kontak ke- } \mathrm{i}
\end{array} \\
& \mathrm{L}=\begin{array}{l}
\text { panjang transek jalur pengamatan } \\
\text { ke } \mathrm{j}(\mathrm{m})
\end{array} \\
& \mathrm{w} \begin{array}{l}
\text { lebar kiri atau kanan jalur } \\
\text { pengamatan ke } \mathrm{j}(\mathrm{m})
\end{array} \\
& \mathrm{a} \quad=\begin{array}{l}
\text { luas setiap jalur pengamatan }\left(\mathrm{km}^{2}\right. \\
\text { atau Ha) }
\end{array} \\
& \mathrm{i} \quad=\begin{array}{l}
\text { kontak pengamat dengan satwa liar } \\
\mathrm{i}
\end{array}
\end{aligned}
$$

Kisaran populasi dugaan per individu jenis untuk seluruh wilayah pengamatan dihitung dengan persamaan King 1971 :

$\hat{P}=\frac{\sum_{i=1}^{n} \mathrm{Xi}}{2 \cdot \sum_{j=1}^{k} L j \cdot w j} \cdot \mathrm{A}$ atau

$\widehat{P}=\frac{\sum_{j=1}^{k} \widehat{D} \mathrm{j}}{k} \cdot A \ldots \ldots \ldots \ldots($ rumus 2$)$

Keterangan :

$\hat{P} \quad=$ ukuran populasi dugaan (individu)

$\widehat{D} \mathrm{j}=$ kepadatan populasi pada jalur pengamatan ke $\mathrm{j}$ (individu/ $\mathrm{km}^{2}$ atau individu/ha)

$\mathrm{k} \quad=$ jumlah jalur pengamatan

$\mathrm{A}=$ luas total area yang diteliti

Untuk menentukan kisaran hasil pendugaan ukuran populasi seluruh jenis satwa liar digunakan persamaan King 1971: 
$\bar{D} \mathrm{j}=\frac{\sum_{j=1}^{k} D j}{k}$ (rumus 3$)$

$\mathrm{S}^{2}{ }_{\mathrm{D}}=\frac{\sum D 2 j-\left(\sum D j\right) 2 / k}{k-1}$

$\mathrm{S} \bar{D}=\sqrt{\frac{\mathrm{S} 2 \mathrm{D}}{k}}$

Keterangan :

$\overline{D_{J}}=$ rata - rata kepadatan populasi dugaan dari seluruh jalur pengamatan (individu $/ \mathrm{km}^{2}$ atau individu/ha)

$\mathrm{Dj}=$ kepadatan populasi pada jalur pengamatan ke-j pengamatan (individu $/ \mathrm{km}^{2}$ atau individu/ha)

$\mathrm{k} \quad=$ jumlah jalur pengamatan

Berdasarkan hasil perhitungan di atas maka kisaran ukuran populasi pada seluruh areal yang diteliti adalah :

$\mathrm{P}=\left[\widehat{D} \pm\left(\operatorname{ta} / 2 ; \mathrm{db} S \bar{D}_{)}\right) . \mathrm{A}\right.$ (rumus 4)

Kelimpahan keanekaragaman jenis satwa liar (wildlife biodiversity) dihitung dengan menggunakan indeks Shanon,

$H^{\prime}=-\sum_{i=1}^{S} p_{i} \ln p_{i}$ (rumus 5)

Keterangan :

$H^{\prime}=$ Indeks kelimpahan satwa liar

$n_{i} \quad=$ Jumlahindividu di dalam spesies

$S \quad=$ Jumlah spesies

$N=$ Jumlah total seluruh individu (komunitas)

$p_{i} \quad=$ Kelimpahan relatif dari setiapspesies yang dihitung dengan perbandingan antara jumlah individu di dalam suatu spesies dengan jumlah total seluruh individu di dalam sebuah komunitas, $p_{i=} \frac{n_{i}}{N}$.

\section{HASIL DAN PEMBAHASAN}

\section{Daya Dukung Lingkungan}

Kebun Percobaan UNB di Cogreg memiliki kapasitas dan daya dukung lingkungan (carrying capacity) sebagai habitat satwa liar. Keberadaan factor faktor daya dukung lingkungan seperti sumber air, keberadaan tegakan JUN dan berbagai jenis tanaman tumpang sari serta tersedianya variasi sumber pakan bagi satwa liar dapat menjelaskan mengapa dapat ditemukan lebih dari satu jenis satwa liar yang berada di Kebun Percobaan UNB.

1. Sumber air

Sumber air berupa sungai kecil (Gambar 3) yang mengalir dan terletak pada jalur pengamatan $\mathrm{X}$ dan beberapa saluran air di sekitar sawah dan perumahan warga yang berbatasan dengan lokasi pengamatan

2. Jenis Tanaman

Beberapa jenis tanaman yang ditemukan antara lain JUN, Kelapa, Pepaya, Padi, Cabe, Singkong, Pisang, Padi, Bambu dan Rumput Ilalang

3. Jenis Serangga

Beberapa jenis serangga yang ditemukan di Kebun Percobaan UNB antara lain, Belalang, Capung, Ulat, Rayap, Lebah, Kupu-Kupu, Tonggeret, Semut, Laba - laba dan Kepik

Secara keseluruhan kondisi dan faktor - faktor daya dukung Kebun Percobaan UNB, Cogreg pada tiap wilayah pengamatan dapat dilihat pada Tabel I.

\section{Karakteristik Satwa Liar}

Pada saat melakukan pengamatan di lapangan, di dapati bahwa banyak sekali Satwa liar yang berinteraksi di daerah oleh tegakan JUN, interaksi itu antara lain mencari pakan, membuat sarang di bawah tegakan hingga melakukan penandaan 
wilayah dan proses mencari pasangan (mating). Jenis - jenis satwa liar dan jalur pengamatannya disajikan pada tabel 2 .

\section{Jenis dan Densitas Satwa Liar}

Berdasarkan hasil pengamatan dan penghitungan diketahui bahwa keanekaragaman jenis satwa liar yang teridentifikasi di Kebun Percobaan UNB adalah sebanyak 16 jenis satwa liar dengan total populasi sebesar 137 individu serta jumlah kelimpahannya sebesar 13,7 individu $/ \mathrm{Ha}^{2}$.

Tabel 1. Kondisi dan Faktor - Faktor Daya Dukung Kebun Percobaan UNB, Cogreg

\begin{tabular}{|c|c|c|c|c|c|}
\hline \multirow{3}{*}{ Jalur } & \multicolumn{3}{|c|}{ Komponen Abiotik } & \multicolumn{2}{|r|}{ Komponen Biotik } \\
\hline & $\begin{array}{l}\text { Iklim/ } \\
\text { Cuaca }\end{array}$ & $\begin{array}{c}\text { Sumber } \\
\text { Air }\end{array}$ & Topografi & Tanaman & Insekta \\
\hline & Sedang & Tersedia & Landai & $\begin{array}{l}\text { JUN, Kelapa, } \\
\text { Pepaya, Bambu }\end{array}$ & $\begin{array}{l}\text { Belalang, Capung, Ulat, Lebah, } \\
\text { Semut, Tonggeret, Kupu - kupu, } \\
\text { Jangkrik, Laba - laba }\end{array}$ \\
\hline I & Sedang & Tersedia & Landai & JUN, Kelapa, Pepaya & $\begin{array}{l}\text { Belalang, Capung, Ulat, Lebah, } \\
\text { Semut, Tonggeret, Kupu - kupu, } \\
\text { Jangkrik }\end{array}$ \\
\hline II & $\begin{array}{l}\text { Sedang } \\
\text { panas }\end{array}$ & - Tersedia & Landai & JUN & $\begin{array}{l}\text { Belalang, Capung, Ulat, Lebah, } \\
\text { Semut, Tonggeret, Kupu - kupu, } \\
\text { Jangkrik }\end{array}$ \\
\hline V & $\begin{array}{l}\text { Sedang } \\
\text { panas }\end{array}$ & $\begin{array}{l}- \text { Tidak } \\
\text { tersedia }\end{array}$ & Landai & JUN, Rumput Ilalang & $\begin{array}{l}\text { Belalang, Capung, Ulat, Lebah, } \\
\text { Semut, Tonggeret, Kupu - kupu, } \\
\text { Jangkrik, Laba - laba }\end{array}$ \\
\hline & $\begin{array}{l}\text { Sedang } \\
\text { panas }\end{array}$ & $\begin{array}{l}- \text { Tidak } \\
\text { tersedia }\end{array}$ & Landai & JUN, Rumput Ilalang & $\begin{array}{l}\text { Belalang, Capung, Ulat, Rayap, } \\
\text { Semut, Kupu - kupu, Tonggeret, } \\
\text { Jangkrik }\end{array}$ \\
\hline I & $\begin{array}{l}\text { Sedang } \\
\text { panas }\end{array}$ & $\begin{array}{c}- \text { Tidak } \\
\text { tersedia }\end{array}$ & Landai & $\begin{array}{l}\text { JUN, } \\
\text { Singkong }\end{array}$ & $\begin{array}{l}\text { Belalang, Capung, Ulat, Lebah, } \\
\text { Tawon, Tonggeret, Kepik, Semut, } \\
\text { Kupu - kupu, Jangkrik, Laba - laba }\end{array}$ \\
\hline II & $\begin{array}{l}\text { Sedang } \\
\text { panas }\end{array}$ & $\begin{array}{l}- \text { Tidak } \\
\text { tersedia }\end{array}$ & Landai & $\begin{array}{l}\text { JUN, Cabe, Pisang, } \\
\text { Padi }\end{array}$ & $\begin{array}{l}\text { Belalang, Capung, Ulat, Rayap, } \\
\text { Semut, Kupu - kupu, Tonggeret, } \\
\text { Jangkrik }\end{array}$ \\
\hline III & $\begin{array}{l}\text { Sedang } \\
\text { panas }\end{array}$ & $\begin{array}{l}- \text { Tidak } \\
\text { tersedia }\end{array}$ & Landai & $\begin{array}{l}\text { JUN, Kelapa, Kapuk, } \\
\text { Sengon, Rumput } \\
\text { Ilalang }\end{array}$ & $\begin{array}{l}\text { Belalang, Capung, Ulat, Lebah, } \\
\text { Tawon, Tonggeret, Kepik, Semut, } \\
\text { Kupu - kupu, Jangkrik, Laba - laba }\end{array}$ \\
\hline $\mathrm{X}$ & $\begin{array}{l}\text { Sedang } \\
\text { panas }\end{array}$ & - Tersedia & Landai & $\begin{array}{l}\text { JUN, Padi, Rumput } \\
\text { Ilalang }\end{array}$ & $\begin{array}{l}\text { Belalang, Capung, Ulat, Lebah, } \\
\text { Semut, Kupu - kupu, Tonggeret, } \\
\text { Jangkrik, Laba - laba }\end{array}$ \\
\hline & $\begin{array}{l}\text { Sedang } \\
\text { panas }\end{array}$ & - Tersedia & Landai & JUN, Jagung, Padi & $\begin{array}{l}\text { Belalang, Capung, Ulat, Lebah, } \\
\text { Tonggeret Kepik, Semut, Kupu - } \\
\text { kupu, Jangkrik, Laba - laba }\end{array}$ \\
\hline
\end{tabular}


Jalur pengamatan yang paling banyak dijumpai satwa liar di dalamnya adalah jalur pengamatan VI dengan jumlah jenis satwa sebanyak 12 jenis dengan total seluruh individu jenis sebanyak 49 individu, sedangkan jalur yang paling sedikit ditemukan satwa liar adalah jalur pengamatan I dan jalur pengamatan II dengan jumlah jenis satwa 2 dan total seluruh individu jenis sebanyak 4 individu untuk jalur pengamatan I dan 6 individu untuk jalur pengamatan II. Banyaknya satwa liar yang berada pada jalur pengamatan VI diduga karena lokasi dekat sumber air, memiliki variasi jenis tanaman dan perkembangan tanaman JUN yang lebih baik dengan jumlah serangga yang lebih beragam sehingga banyak satwaliar yang tertarik untuk berada di lokasi ini,baik yang sekedar mencari makan maupun yang menjadikannya sebagai habitat. Adapun untuk lokasi pengamatan yang sedkit satwanya, hal ini diduga karena lokasi kurang mendapatkan perawatan, tanaman JUN yang ada kurang baik pertumbuhannya, sedikit atau tidak ada tanaman tumpang sari dan tanaman sela dari jenis lain serta agak jauh dari lokasi sumber air.

Jumlah satwa liar yang paling banyak ditemukan di Kebun Percobaan UNB ini adalah Walet Sapi (Collocalia linchi) sebanyak 33 individu, dengan kisaran populasi 2 individu hingga 64 individu yang terdapat di alam, serta Kutilang ((Pycnonotus aurigaster) sebanyak18 individu, dengan kisaran populasi 0 individu hingga 41 individu yang terdapat di alam. Fenomena ini dapat dijelaskan dengan rendahnya Decimating factors (faktor - faktor yang langsung menyebabkan kematian) dan tingginya Welfare factors (faktor - faktor yang sangat mempengaruhi kualitas lingkungan hidup pada satwaliar) serta Influencin factors (factor - faktor yang berpengaruh pada kualitas dan kuantitas makanan, air, pelindung dan ruang) bagi Walet Sapi dan Kutilang.

Walet Sapi dan Kutilang memiliki daya adaptasi yang baik dengan lingkungan yang terdapat aktifitas manusia di dalamnya. Hal ini dapat dilihat dengan kemampuan satwa ini membangun sarang dibangunan - bangunan yang didirikan dan dipergunakan oleh manusia.

Dengan kemampuan Walet Sapi yang berkembang biak dan bertelur sepanjang tahun (J. MacKinnon, K. Phillipps dan B. Van Balen, 2000), juga dapat menjelaskan kenapa satwa ini merupakan satwa yang paling sering ditemukan di Kebun Percobaan UNB. Melimpahnya ketersediaan pakan bagi kedua satwa liar ini di Kebun Percobaan UNB yakni, jenis - jenis serangga serta tidak adanya predator seperti elang, alap alap dan perburuan manusia yang menjadi ancaman utama Walet Sapi dan Kutilang juga menjadi penyebab melimpahnya kedua jenis Satwa Liar ini.

Adapun jenis satwa liar yang jarang ditemukan adalah Ular Koros dan Ulrtali picis, yakni sebesar 1 individu dengan kisaran populasi 4 individu yang terdapat di alam. Tingginya Decimating factors (faktor - faktor yang langsung menyebabkan kematian) dan rendahnya Influencin factors (faktor - faktor yang berpengaruh pada kualitas dan kuantitas makanan, air, pelindung dan ruang) bagi Ular koros dan Ular Tali Picis merupakan penyebab kenapa kedua satwa liar ini sangat sulit ditemukan di Kebun Percobaan UNB.

Cahaya matahari yang terik dan suhu yang panas di daerah Kebun Percobaan UNB serta perubahan cuaca yang tidak menentu, diduga mengakibatkan penurunan gairah kedua jenis Ular ini dalam berkembang biak, karena menurut pernyataan R. B. Stuebing \& R. F bahwa berkurangnya panjang siang hari dan menurunnya suhu udara merupakan faktor pendorong yang merangsang musim kawin. Selain itu satwa ini seringkali dibunuh petani JUN yang merasa takut dengan keberadaan Ular atau sengaja untuk diambil daging dan kulitnya.

Saat ini penelitian mengenai satwa liar ini telah dilakukan sebanyak 2 kali yaitu pada tahun 2009 dan 2011. Dari hasil analisa data diketahui bahwa telah ditemukan berbagai jenis satwa liar dengan populasi yang bervariasi. Data jenis satwa 
liar dan populasinya disajikan dalam Tabel 3.

Dari Tabel 3 tersebut diketahui bahwa telah ditemukan sebanyak 22 jenis satwa liar. Pada penelitian tahun 2009 ditemukan sebanyak 19 Jenis satwa sedangkan penelitian tahun 2011 telah menemukan sebanyak 16 jenis satwa. Dengan demikian terdapat beberapa jenis satwa yang hanya ditemukan pada tahun 2009 atau 2011 dan ada jenis satwa yang sama ditemukan pada penelitian 2009 dan penelitian 2011 .

Tabel 2. Jenis satwa dan sebarannya di Jalur Pengamatan

\begin{tabular}{|c|c|c|c|c|c|c|c|c|c|c|c|c|}
\hline \multirow{2}{*}{ No } & \multirow{2}{*}{ Jenis Satwa Liar } & \multicolumn{10}{|c|}{ Kepadatan Populasi } & \multirow{2}{*}{ Jumlah } \\
\hline & & I & II & III & IV & $\mathrm{V}$ & VI & VII & VIII & IX & $\mathrm{X}$ & \\
\hline 1 & $\begin{array}{l}\text { Kadal Kebun } \\
\text { (Mabuya } \\
\text { multifasciata) }\end{array}$ & 2 & 3 & 1 & 2 & 1 & 2 & 1 & 1 & 3 & 1 & 17 \\
\hline 2 & $\begin{array}{l}\text { Ular Koros (Ptyas } \\
\text { korros) }\end{array}$ & 0 & 0 & 1 & 0 & 1 & 0 & 0 & 0 & 0 & 0 & 2 \\
\hline 3 & $\begin{array}{l}\text { Ular Tali picis } \\
\text { (Dendrelaphis pictus) }\end{array}$ & 0 & 0 & 0 & 0 & 0 & 1 & 0 & 0 & 0 & 0 & 1 \\
\hline 4 & $\begin{array}{l}\text { Burung Wiwik } \\
\text { (Cacomantis } \\
\text { merulinus) }\end{array}$ & 0 & 0 & 0 & 0 & 0 & 0 & 0 & 0 & 1 & 0 & 1 \\
\hline 5 & $\begin{array}{l}\text { Burung Puyuh } \\
\text { (Cortunix cortunix) }\end{array}$ & 0 & 0 & 0 & 1 & 0 & 2 & 0 & 0 & 1 & 0 & 4 \\
\hline 6 & $\begin{array}{l}\text { Burung Walet Sapi } \\
\text { (Collocalia linchi) }\end{array}$ & 2 & 2 & 4 & 1 & 6 & 11 & 0 & 0 & 1 & 6 & 33 \\
\hline 7 & $\begin{array}{l}\text { Burung Kapinis } \\
\text { Rumah (Apus afinis) }\end{array}$ & 0 & 1 & 2 & 0 & 0 & 4 & 0 & 0 & 0 & 1 & 8 \\
\hline 8 & $\begin{array}{l}\text { Burung Tekukur } \\
\text { (Streptopelia } \\
\text { chinensis) }\end{array}$ & 0 & 0 & 2 & 0 & 0 & 11 & 0 & 0 & 0 & 4 & 17 \\
\hline 9 & $\begin{array}{l}\text { Burung Perenjak } \\
\text { (Prinia familiaris) } \\
\text { Burung Kutilang }\end{array}$ & 0 & 0 & 0 & 0 & 0 & 1 & 0 & 0 & 1 & 0 & 2 \\
\hline 10 & $\begin{array}{l}\text { (Pycnonotus } \\
\text { aurigaster) } \\
\text { Burung Cinenen }\end{array}$ & 0 & 0 & 6 & 4 & 0 & 6 & 0 & 0 & 0 & 2 & 18 \\
\hline 11 & $\begin{array}{l}\text { Pisang (Orthotomus } \\
\text { sutorius) }\end{array}$ & 0 & 0 & 2 & 2 & 0 & 4 & 1 & 0 & 0 & 2 & 11 \\
\hline 12 & $\begin{array}{l}\text { Burung Cici Padi } \\
\text { (Cisticola juncidis) }\end{array}$ & 0 & 0 & 1 & 1 & 0 & 2 & 0 & 0 & 0 & 0 & 4 \\
\hline 13 & $\begin{array}{l}\text { Burung Gereja } \\
\text { (Passer montatus) }\end{array}$ & 0 & 0 & 0 & 0 & 2 & 0 & 0 & 0 & 0 & 0 & 2 \\
\hline 14 & $\begin{array}{l}\text { Burung Pipit / Bondol } \\
\text { (Lonchura punctulata) }\end{array}$ & 0 & 0 & 0 & 2 & 0 & 3 & 0 & 0 & 2 & 0 & 7 \\
\hline 15 & $\begin{array}{l}\text { Garangan } \\
\text { (Viverriculla indica) }\end{array}$ & 0 & 0 & 0 & 2 & 0 & 2 & 0 & 0 & 1 & 0 & 5 \\
\hline 16 & $\begin{array}{l}\text { Kalong (Pteropus } \\
\text { vampyrus) }\end{array}$ & 0 & 0 & 2 & 0 & 1 & 0 & 1 & 1 & 0 & 0 & 5 \\
\hline & Total & & & & & & & & & & & 137 \\
\hline
\end{tabular}


Tabel 3. Jenis Satwa Liar dan Populasinya di Tegakan JUN Cogreg

\begin{tabular}{clcc}
\hline No & \multicolumn{1}{c}{ Jenis Satwa Liar } & $\begin{array}{c}\text { Populasi Rata - rata } \\
\text { (Individu/ ha) Tahun 2009 }\end{array}$ & $\begin{array}{c}\text { Populasi Rata - rata } \\
\text { (ndividu/ ha) Tahun } \\
\text { 2011 }\end{array}$ \\
\hline 1 & Kadal Kebun & 3.1 & 1.7 \\
2 & Ular Pucuk & 0.5 & 0 \\
3 & Ular Sanca Kembang & 0.1 & 0 \\
4 & Ular Koros & 0 & 0.2 \\
5 & Ular Tali Picis & 0 & 0.1 \\
6 & Burung Wiwik & 9.1 & 0.1 \\
7 & Burung Puyuh & 12 & 0.4 \\
8 & Burung Walet Sapi & 16.4 & 3.3 \\
9 & Burung Kapinis Rumah & 11.7 & 0.8 \\
10 & Burung Tekukur & 1.7 & 1.7 \\
11 & Burung Perenjak & 1.5 & 0.2 \\
12 & Burung Kepodang & 0.6 & 0 \\
13 & Burung Kutilang & 1.8 & 1.8 \\
14 & Burung Cinenen Pisang & 1.1 & 1.1 \\
15 & Burung Cici Padi & 9.6 & 0.4 \\
16 & Burung Gereja & 11 & 0.2 \\
17 & Burung Pipit (Bondol) & 0 & 0.7 \\
18 & Bajing Kelapa & 0.1 & 0 \\
19 & Musang Luwak & 0.3 & 0 \\
20 & Kucing Hutan & 0.3 & 0 \\
21 & Garangan & 0.5 & 0.5 \\
22 & Kalong & 9.6 & 0.5 \\
\hline
\end{tabular}

Perbandingan jumlah jenis satwa liar tahun 2009 dan 2011 menunjukkan bahwa sebesar 59,09\% atau sebanyak 13 jenis satwa liar ditemukan pada penelitian 2009 dan 2011. Sebesar 27,27\% atau sebanyak 6 jenis satwa liar yang hanya ditemukan pada tahun 2009. Sebesar 13,64 $\%$ atau sebanyak 3 jenis satwa liar yang hanya ditemukan pada tahun 2011.

Terkait dengan penemuan jenis satwa liar tersebut, populasi rata - rata pun terjadi perbedaan. Fluktuasi Populasi rata rata jenis satwa liar.

Dari perbandingan kepadatan populasi rata-rata jenis satwa antara tahun 2009 dan tahun 2011 yang disajikan pada grafik tersebut dapat terlihat adanya populasi yang menurun, meningkat dan tetap. Terdapat 15 Jenis satwa liar yang populasi rata - ratanya menurun, 3 jenis satwa meningkat, dan sebanyak 4 jenis satwa populasi rata - ratanya tetap.

Selain perbandingan populasi tersebut analisa, data inventarisasi jenis satwa liar dibandingkan juga yaitu indeks keanekaragaman jenis, indeks kemerataan jenis. Nilai indeks tersebut disajikan dalam table 4.

Indeks kekayaan jenis pada tahun 2009 adalah sebesar 2.33 dan tahun 2011 sebesar 2.35. Dengan demikian keanekaram an jenis pada tahun 2009 dan tahun 2011, keduanya masuk dalam kriteria keanekaragaman sedang.

Berdasarkan hukum Margalef 1972 di dalam skripsi Insan 2003 dan Dorkas Soli 1999, diketahui bahwa keanekaragaman jenis satwa liar dikatakan rendah bila memiliki indeks Shanon < 1,5, sedang 1,5 - 3,5 dan besar > 3,5. Berdasarkan penilaian Margalef tersebut maka keanekaragaman jenis satwa liar di Kebun Percobaan UNB tergolong sedang dengan nilai indeks 2,33 pada tahun 2009 dan 2,35 pada tahun 2011. Dengan demikian berdasarkan keberadaan keanekaragaman jenis satwaliar yang ada di KebunPercobaan UNB dapat dilakukan 
sebuah pendugaan bahwa kawasan ini belum terlalu tercemar lingkungannya dan masih memiliki alam yang sehat.

Nilai indeks kemerataan jenis pada tahun 2009 adalah 0,79 sedangkan tahun 2011 adalah 0,85 , hal tersebut menunjukkan jenis satwa liar yang ditemukan pada tahun 2011 lebih merata atau jenis yang mendominasi lebih rendah dari pada tahun 2009.

Nilai indeks kekayaan jenis Margalef pada tahun 2009 adalah 2,64, sedangkan tahun 2011 adalah sebesar 3,05. Nilai indeks kekayaan margalef pada tahun 2011 lebih tinggi dari pada tahun 2009, hal tersebut diperkuat dengan nilai indeks keanekaragaman jenis dan kemerataan jenis pada tahun 2011 lebih tinggi dari pada tahun 2009.

Perbandingan nilai indeks keanekaraman, indeks kemerataan dan indeks kekayaan jenis pada tahun 2009 dan 2011 disajikan dalam Gambar1.

Satwa liar memiliki fungsi ekologis yang khas dan saling bertautan antara keberadaan satwa liar dengan satwa liar lainnya yang berimbas langsung terhadap kondisi habitat dan lingkungan alam. Bangsa Aves pada Kebun Percobaan UNB memiliki fungsi ekologis antara lain sebagai predator serangga atau hama yang menyerang tanaman sehingga populasi hama tidak berlebihan jumlahnya, sebagai penyebar benih bagi tanaman melalui feses ataupun sisa biji tanaman yang tidak ikut termakan dan sebagai sumber pakan bagi satwa predator lain, terutama dari jenis reptile, mamalia dan aves yang lebih besar dan karnivora. Burung wiwik sering sekali dijadikan sebagai penanda akan datangnya musim hujan, ketika terdengar banyak suara kicauannya.

Bangsa Reptil pada Kebun Percobaan UNB memiliki fungsi ekologis sebagai predator hama,baik yang merusak tanaman (serangga) maupun yang merusak susunan dan kondisi kepadatan tanah seperti halnya tikus. Ular koros contohnya,dapat menekan populasi tikus, sehingga secara ekologis ikut membantu menjaga kondisi alami tanaman dan tanah dari kerusakan. Karena di Kebun Percobaan UNB ini juga banyak terdapat sawah, keberadaan Ular koros juga ikut menguntungkan petani,karena satwa ini akan memangsa hama bagi tanaman padi yakni tikus sawah dan juga beberapa burung yang memakan benih padi seperti burung puyuh dan gereja. Bangsa Mamalia pada Kebun Percobaan UNB memiliki fungsi sebagai penyebar benih (Kalong) dan sebagai pakan sekaligus predator (Garangan) bagi satwa liar lainnya.

Disamping memiliki nilai ekologis yang penting, Satwa liar juga memiliki nilai ekonomis yang cukup besar. Ular koros misalnya, memiliki nilai jual yang cukup tinggi, karena daging dan kulit ular ini dapat dimanfaatkan (daging untuk obat kuat dan obat penyakit kulit, sedangkan kulit disamak untuk dijadikan tas, sepatu dan pernak - pernik lain). Selain itu Ular yang tidak berbisa biasanya juga dapat diperdagangkan sebagai hewan peliharaan, demikian pula dengan Ular koros dan Ular tali picis.

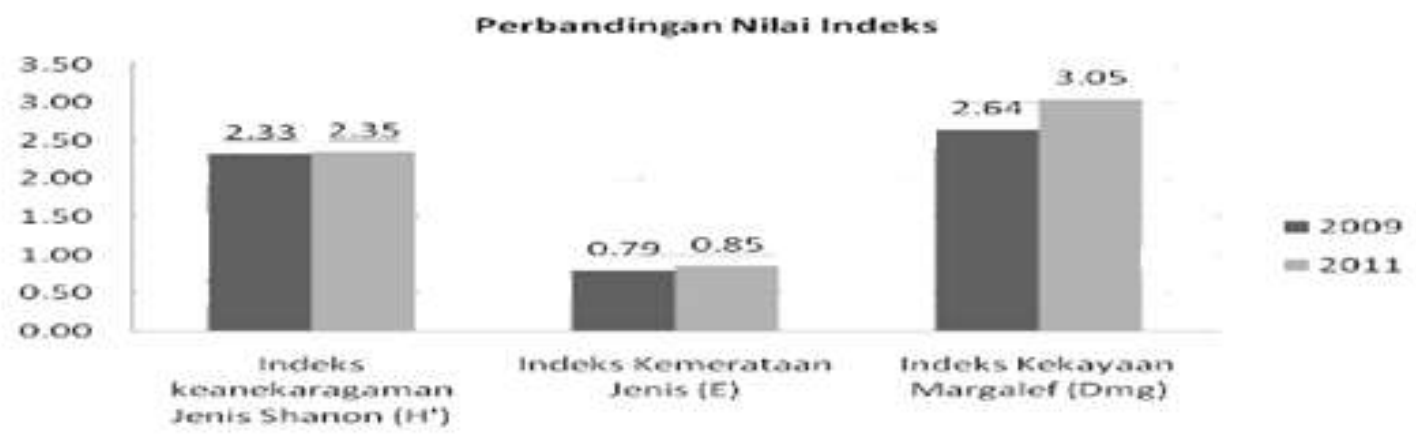

Gambar 1. Perbandingan Nilai Indeks Keragaman, Kemerataan dan Kekayaan Jenis Tahun 2009 dan 2011 
Burung Tekukur biasanya dijadikan sebagai burung hias,burung balap maupun untuk dikonsumsi dagingnya, adapun untuk burung Perenjak Jawa, Kepodang, Kutilang, Cinenen Pisang biasanya dijadikan sebagi burung hias atau burung galatama (kontes burung berkicau) yang nilainya dapat mencapai puluhan juta rupiah.

Mengingat keberadaan satwa liar yang khas dan penting sebagai penjaga keseimbangan ekosistem maka sudah seharusnya keberadaan satwa liar beserta habitatnya perlu dipertahankan serta diberikan perhatian khusus sehingga keberadaan satwa tetap terjaga.

Berdasarkan penuturan beberapa petani yang telah lama tinggal atau bekerja di daerah Kebun Percobaan UNB, beberapa satwa liar yang dijumpai di sini merupakan satwa yang tidak umum dijumpai sebelumnya, mengingat kondisi Kebun Percobaan UNB dulunya didominasi ilalang dan tidak terawat.Keberadaan kegiatan penanaman JUN serta kondisi lingkungan yang membaik di duga ikut mempengaruhi keberadaan satwaliar tersebut di daerah Kebun Percobaan UNB ini.

\section{KESIMPULAN DAN SARAN}

\section{Kesimpulan}

1. Pada Kebun Percobaan UNB, Cogreg teridentifikasi sebanyak 16 satwa liar dari tiga kelas satwa (reptile, aves dan mamalia) antara lain Kadal Kebun, Ular Koros, Ular Tali Picis, Burung Wiwik Kelabu, Burung Puyuh, Walet Sapi, Kapinis, Tekukur, Perenjak, Kutilang, Cinenen Pisang, Cici Padi, Burung Gereja, Burung Pipit/Bondol, Garangan dan Kalong.

2. Populasi satwa liar yang teridentifikasi di Kebun Percobaan UNB sebesar 137 individu dan jumlah kelimpahannya sebesar 13,7 individu/Ha2. Keanekaragaman Jenis Satwa Liar di Kebun Percobaan UNB tergolong sedang dengan nilai indeks sebesar 2,35. Satwa liar yang paling banyak ditemukan adalah Walet Sapi, Kutilang, kadal kebun dan Tekukur.

\section{Saran}

Keberadaan satwa liar perlu dipertahankan, karenanya diperlukan masukan dan penyuluhan terhadap masyarakat sekitar mengenai nilai dan pentingnya keberadaan satwa-satwa ini serta hubungannya dengan keseimbangan ekosistem dan pengaruhnya terhadap kehidupan masyarakat.

\section{DAFTAR PUSTAKA}

Alikodra, H. S., 1989. Pengelolaan Satwa liar. Volume I. PAU Ilmu Hayat IPB. Tidak Diterbitkan. Bogor.

1990. Pengelolaan Satwaliar. Volume II. PAU Ilmu Hayat IPB. Tidak Diterbitkan. Bogor.

Corbet, G. B and J. E. Hill., 1992, The Mammals of the Indomalayan Region : a systematic review. Nat. Hist. Mus. Publ. and Oxford Univ. Press.

Cranbrook, Earl of., 1987, Riches of the Wild : land mammals of South-east Asia. Oxford Univ. Press, Singapore

The World Conservation Monitoring Center., 1992. A report compiled by Global Biodiversity Status of The Earth Living Resources. Chapman \& Hall. UK.

David, P \& G. Vogel., 1997. The Snakes of Sumatra. An annotated checklist and key with natural history notes.Edition Chimaira.Frankfurt.

Dima, Dorkas Soli., 1999. Studi Keanekaragaman Jenis Satwa liar pada Areal Bekas Kebakaran Taman Nasional Way Kambas Provinsi Lampung. Jurusan Konservasi Sumberdaya Hutan. Institut Pertanian Bogor. Skripsi 
Hayssen, V., A. Van Tienhoven, A. Van Tienhoven, S. Asdell., 1993. Asdell's Patterns of Mammalian Reproduction: A Compendium of Species-specific Data. Ithaca : Cornell University Press

Kurnia, Insan, 2003. Studi Keanekaragaman Jenis Burung untuk Pengembangan Wisata Bird Watching di Kampus IPB Dramagai Jurusan Konservasi Sumberdaya Hutan.Institut Pertanian Bogor. Bogor. Skripsi

Mackinnon. J., 1993. Panduan Lapangan Pengenalan Burung - burung di Jawa \& Bali. Sukianto, L dan Yeni A. M. (penerjemah). Gadjah Mada University Press. Bulaksumur. Yogyakarta.

MacKinnon, J., K. Phillipps dan B. van Balen. 2000. Burung - burung di Sumatera, Jawa, Bali dan Kalimantan. LIPI dan BirdLife IP. Bogor.

Mahfudz dkk.,1994. Sekilas Jati. Puslitbang Biotek dan Pemuliaan Tanaman Hutan. Yogyakarta.

Mattison, C., 1999. Snake. New York, NY: DK publishing, Inc.

Moen, A. N., 1973. Wildlife Ecology. Wh Freeman and Company. San Francisco.

Murphy, J., R. Henderson., 1997. Tales of Giant Snakes. Malabar, Fl : Krieger publishing company.

Nowak, R., E. Walker, D. Mac. Donald, R. Kays., 2005. Walker's Carnivores of the World. New York : JHU Press.

Odum, E. P., 1971. Fundamental of Ecology (Thrid Edition).WB Soundres Co. Philadelphia-LondonToronto.
Payne, Junaidi, Charles M. Francis, Karen Phillipps., 1993. Panduan Lapangan Pengenalan Mamalia di Kalimantan, Sabah, Sarawak \& Brunei Darussalam. Sri Nurani Kartikasari. (penerjemah). The Sabah Society and Wildlife Conservation Society. Jakarta.

Roots, C., 2006. Nocturnal Animals. New York : Greenwood Publishing Group.

Shine, R., Ambariyanto, PS Harlow, Mumpuni. 1999. Reticulated pythons in Sumatra, harvesting and sustainability. Biological Conservation. Jakarta.

Soeroso H \& Soetadjo D. P., 2008. Usaha tani Jati Unggul Pola Bagi Hasil 5 Tahun Panen, cetakan IV. Jakarta.

Supardi, I., 1994. Lingkungan Hidup dan Kelestariannya Edisi Kedua. Cetakan I. Penerbit Alumni. Bandung.

Stuebing, R. B \& R. F. Inger, 1999. A Field Guide to The Snakes of Borneo. Natural History Publications (Borneo). Kota Kinabalu.

Tate, G., 1947. Mammals of Eastern Asia. New York : MacMillan Company.

Tweedie, M. W. F., 1983. The Snakes of Malaya. The Singapore National Printers. Singapore.

Tweedie, M. W. F. and J. L. Harrison, 1988, Malayan Animal Life, Longman, Petaling Jaya, Selangor Darul Ehsan.

Wiersum, K. F., 1973. Wildlife Utilization and Management in Tropical Region Agricultural University. Nature Conservation Departemen. Wargeningen. 